\title{
Withdrawing the Case of Uganda from the Jurisdiction of the International Criminal Court
}

\section{Sebastien Malo'}

Masters of International Affairs,

Graduate Institute of International and Development Studies,

Geneva, Switzerland

Sebastien Malo holds a Masters of International Affairs from the Graduate Institute of International and Development Studies in Geneva. He worked from the Department of Foreign Affairs and International Trade of Canada in 2008-2009, and is currently the Middle East and North Africa Editor for The Daily Star, a newspaper in Beirut, Lebanon.

\section{Can Alternative Justice Mechanisms Offer a Substitute to Prosecutions?}

The trend from international armed conflicts toward internal insurgencies has altered our common understandings of classical strategic wisdom. While traditionally under the politics of imperialism, wars were settled with the winning state's decisive acquisition of territories over that of another state, in internal conflicts rebels choose to protract asymmetric warfare by employing low-scale guerrilla tactics rather than attempting to decisively hold a territory. Clausewitz's observation that war is a mere continuation of politics by other means is thus nuanced by the unlikelihood that the solution to those long-lasting conflicts will be of a military nature, flipping the logic of Clausewitz's maxim on its head - politics as war by other means. As a result, burdened with such intractable conflicts, governments are often forced to make political gains through political negotiations instead of through military conflict.

Another element of the modern international system however clashes with this imperative to negotiate for peace. Under the precepts of international law, states are compelled to prosecute rebels for crimes committed during war. Ironically, as many commentators have already argued, this constraining force may do more to hinder the process of peace than to abet it. In this sense, international law obligates states to maintain an antagonistic stance toward rebels, while concurrently negotiating for peace.
Nonetheless, politics implies bargaining, and when negotiating to end internal insurgencies, the ransom for peace often consists of rebels demands for immunity from charges. States are thus confronted with a dilemma: if peace and justice are exclusive, which should they pursue?

An archetypal case study is that of Uganda, where the state has been struggling against an armed group, the Lord's Resistance Army (LRA), for more than 20 years during which the warring parties have allegedly committed numerous international crimes. Recently, peace has finally seemed attainable as promising negotiations between the government and the LRA known as the Juba talks were launched in 2006 , only to be derailed in 2008 by the apparent indecision of the rebels. The LRA is now reportedly active in the adjacent Democratic Republic of Congo, the Central African Republic, and South Sudan, leading many to conclude that the peace process has definitely collapsed. Only a few months after the failure of its latest military offensive, and more than two decades since it first resorted to that strategy, the Ugandan government is debating again launching a new offensive. ${ }^{2}$ For several observers and stakeholders, the origin of this momentary failure can be traced to a 2004 request by the Ugandan government to involve the International Criminal Court (ICC), after which ICC prosecutor Luis Ocampo-Moreno issued five arrest warrants for top LRA commanders. ${ }^{3}$ 
Predictably, while the ICC was attempting to ensure that justice would be provided to victims, peace negotiations were turning sour over that same issue.

It is worth asking: can ICC prosecutions really contribute to a sense of justice? If not, are there alternative means of fostering both peace and justice? Can these alternative means of administering justice legally replace prosecutions under the twofold legal framework of general international law, and of the Statute of the ICC? This article will argue that although the ICC attempts to further justice in Uganda, its prosecutions may not be the most effective way to contribute to that goal. In this regard, it will be suggested that the peace vs. justice schema only offers a tunnel view of available alternatives to address violations. Measures that are nonprosecutorial and quasi-judicial potentially offer a much greater contribution to both peace and justice than ICC prosecutions. Whether there is a legal basis for the replacement of the ICC prosecutions by these mechanisms is however disputed. The legality of conditional amnesties is at the forefront of this debate. Yet, after a careful examination of all legal considerations, we will conclude that international law, at large, as well as statutory law, offer enough leeway for certain types of alternative justice mechanisms to lawfully replace ICC prosecutions. Building on that conclusion, this article will argue that the ICC should recognize herein an opportunity to further its goal of ending impunity, and choose to favor an interpretation of law that accommodates it.

\section{The Peace vs. Justice Dilemma in Uganda}

The ICC indictments were initially saluted across Uganda. But in countries experiencing internal conflict such as Uganda, the notions of peace and justice are often difficult to reconcile. Or rather, their reconciliation exposes priorities that are at odds in the short-term, but, in the long-term, necessary for stability. ${ }^{4}$

Observers both within and outside Uganda have weighed in on this peace vs. justice dilemma with opinions on where the emphasis should be placed differing vastly. On the one hand, political actors such as the United Nations and prominent human rights groups have been in favor of maintaining the ICC indictments. ${ }^{5}$ Accountability for international crimes, they argue, constitutes a strong foundation upon which peace and stability can be built and sustained. On the other hand, a vocal faction of Ugandan officials and local Acholi leaders has argued that the ICC indictments are a major political obstacle to peace by short-circuiting the amnesty and reconciliation process and prolonging the war. ${ }^{6}$ Their stance is motivated by declarations by the rebels to the effect that signing a peace agreement is contingent upon being absolved from formal criminal responsibility. ${ }^{7}$ Similarly, some members of the international community have firmly maintained that the trade-off with peace is untenable. Even major international bodies such as the United Nations Security Council (Security Council) have weighed out the possibility of ending the prosecutions. ${ }^{8}$

The recent resurgence of LRA attacks has seriously reshaped the debate about the halting or straight out withdrawal of the ICC prosecutions over the Ugandan rebel leaders. Nevertheless, although peace is now much more elusive than it has ever been in recent years, this debate's apparent anachronism may only be temporary. Indeed, claims by security experts that the LRA was weakened in 2005 when Sudan withdrew its support to the group still prevail. The Security Council has also recently agreed that the government of Uganda should continue its peace efforts. ${ }^{9}$ The LRA, in other words, may still be enticed to the negotiation table. It is, thus, still worth taking a step back and exploring alternative options to the ICC program of prosecutions. When this time comes, the international community should avoid a repetition of history, and 
come prepared to respond to demands that it decides on peace or justice - that is, halting the prosecutions, or seeing the conflict resume again.

\section{Can There Be Justice Beyond Law? Traditional Justice and TRCs}

Scholars have long pondered about the competing value of prosecution against that of alternative means of justice such as traditional justice mechanisms when comparing the notions of retributive and restorative justice. Retributive justice systems, such as that embodied by the ICC, seek to redress violations of the law through punishment. However, one can argue that justice can also be defined in other terms. Sociologists of law and critical legal scholars emphasize the importance of deconstructing law, so as to make visible the purpose a specific law serves, its moral intent aside, in a given context. ${ }^{10}$ Mark A. Drumbl argues that, despite the near universality of the ideas of repudiating great evil and the need for accountability for victims, the categorization of great evils as crimes is less certain. The artificiality of the universalism of international criminal law seems starkest at the procedural level. ${ }^{11}$ Indeed, as Drumbl argues:

The modalities of international criminal law, in particular those related to punishment and sentence, tend to universalize through ideological preference instead of through an independent assessment of the social psychology of the violence [...] [But t] he choices are not binary: namely, either to accept the received wisdom of existent internationalized institutions, on the one hand, or the void of impunity. ${ }^{12}$

It is in this perspective that alternative approaches to justice, such as the restorative approach, have undertaken to redefine the responses to crimes.

Ugandan traditional justice mechanisms were initially championed as substitutes to ICC prosecutions on grounds echoing those put forward by critical legal scholarssuch as Drumbl. Indeed, dissatisfaction with ICC prosecution has led scores among those opposing ICC prosecutions to question the rationale and impact of an eventual sentencing of perpetrators by the ICC, arguing that it would likely not have a preventive effect in the community. In comparison, they claim, traditional justice is more suited given that it prioritizes reconciliation and reintegration. ${ }^{13}$ There are several ceremonies that are traditionally practiced by northern Ugandans which act as retributive mechanisms. Mato Oput (meaning 'drinking of the bitter herb or root') is the main one discussed as suitable for Joseph Kony and other LRA members, particularly those sought by ICC arrest warrants..$^{14}$ Mato Oput is traditionally used to resolve inter-clan disputes, such as the killing of a clan member by an individual of another clan. ${ }^{15}$ In terms of its purpose, it is "...both a process and a ritual ceremony to restore relationships between clans in the case of intentional murder or an accidental killing." ${ }^{\prime 16}$

The effectiveness and viability of such traditional methods to administer justice was, however, recently put into question. In essence, their inappropriateness stems from the fact that they were originally intended to deal with single violations, and were only recently transformed into mechanisms to administer justice for larger conflicts. By many accounts, such adapted ceremonies may have little or no resonance with the local population and on their willingness to forgive the perpetrators. ${ }^{17}$

The debate that has surrounded the substitution of ICC prosecutions with traditional justice mechanisms, although offering no clear answer, has had the merit of opening a breach into the prevalent view among decision-makers that retributive means of accountability are always the preferred way to hold individuals accountable for their international crimes. Specifically, this debate has directed researchers to measure opinions among Ugandans about other transitional justice mechanisms, often inspired by the notion of restorative justice. The recognition that truth and reconciliation commission 
(TRC) was another popular alternative to prosecution has emerged as the fruits of their labors. In that regard, a widely cited recent survey conducted with Northern Ugandans reveals that 92 percent of respondents agreed that a truth-telling process was needed in Uganda. ${ }^{18}$

\section{"Measures that are non-} prosecutorial and quasi-judicial potentially offer a much greater contribution to both peace and justice than ICC prosecutions."

TRCs rest on the principle of reconciliation versus punishment that advocates of the notion of retributive justice have defended. They generally involve the establishment of a quasi-judicial body, with a fact-finding mandate but no direct power to punish offenders. Their goal is the reconstruction of the history of a certain period to facilitate reconciliation in a given society. Full amnesty for the perpetrators of international crimes usually depends upon completion of their testimony. In other circumstances, TRCs have been widely discussed as capable, if conducted genuinely, of providing justice. ${ }^{19}$

The arguments that favor restorative justice mechanisms tend to assume one of two forms - which echo those of stakeholders in favor of substituting ICC prosecutions in Uganda. The first is legal. It allows that restorative justice mechanisms offer a superior form of justice when a state has faced mass atrocities, irrespective of political compromises. For instance, Martha Minow argues that TRCs, "... are not a second best alternative to prosecutions... When the societal goals include restoring the dignity to victims, offering a basis for individual healing, and also promoting reconciliation across a divided nation, a truth commission may be more powerful than prosecution." ${ }^{\prime 20}$ That is, restorative justice may allow breaking the cycle of violence by gaining insights into what occurred in the past and why. Retributive justice may not be capable of obtaining this understanding because it considers that a violation of law is centered around the offence to the state rather than to the victim ${ }^{21}$ The state "...therefore, essentially owns the conflict and determines how to respond to it", while victims and offenders are to some extent subsidiary to the process. ${ }^{22}$ Instead, restorative justice recognizes crime as being primarily directed against individuals. Those who are most affected by the crimes should thus become actively involved in resolving the conflict. 23

Furthermore, some argue that restorative justice mechanisms may also be preferable politically. Recalcitrant perpetrators may be more likely to participate in restorative mechanism than to expose themselves to the demands of a tribunal in societies where power is fragmented and perpetrators are capable of resisting arrest. Thus, even if under ideal circumstances prosecutions might be preferable, non-prosecutorial restorative alternatives may be justified as a necessary political compromise for a peaceful coexistence. In that sense, alternative mechanisms may achieve greater justice than that which would be realized by retributive justice. $^{24}$

The conundrum of whether the termination of the ICC prosecutions would lead to peace is certainly complex, and this discussion does not pretend to bring closure to this debate. ${ }^{25}$ Nevertheless, building on the tentative conclusion that prosecutions at large may not be the preferable way to establish justice in Uganda, this article will focus on testing the legality of replacing ICC prosecutions with alternative means of justice, i.e. TRCs, or traditional justice mechanisms. We will measure these alternative means of justice against the precepts of general international law, as well as against the ICC's statutory law. The Legality of Alternative Justice Mechanisms in the Context of an ICC Prosecution.

\section{Legal Basis of Alternative Justice Mechanisms in General}




\section{International Law}

Three mechanisms allow for the withdrawal of a case under ICC's jurisdiction. They are the Security Council deferral, the prosecutorial discretion to abandon a case on the basis of the interests of justice, and the challenge of the Court's jurisdiction on the basis of the principle of complementarity.

To decide whether the alternative mechanisms of justice identified above - TRCs and traditional means of justice - can replace the ICC prosecutions, one must initially consider the general legal framework. General international law regulates all withdrawal mechanisms and, in some cases, may per se make it unlawful to withdraw a case.

When considering the validity of the legal basis of alternative means of justice, one essentially considers a delimited area, where law and extra-legal mechanisms meet. Indeed, although they are extra-judicial, alternative justice mechanisms are paired with a judicial status providing them with a legal context. To that effect, the 2000 Amnesty Act was adopted in Uganda before there were discussions of traditional justice. Its proponents have suggested that when a case is handled with traditional justice, it is to be paired with the granting of domestic amnesties on the judicial level. ${ }^{26}$ Similarly, a Ugandan TRC could conclude with the granting of domestic amnesties to most criminals dealt with, if not all.

In order to determine whether a case could lawfully be withdrawn from the ICC, it is necessary to assess whether the state's decision not to prosecute through the amnesty of alleged perpetrators is valid under general rules of law. If it is valid, domestic and international courts can recognize amnesty for international crimes. The most relevant rules of international law for this discussion are those governing the obligation to prosecute. ${ }^{27}$

The premise we follow is that if the obligation to prosecute clashes with the granting of amnesty, it will also conflict, by extension, with the alternative justice mechanisms being employed. In such a circumstance, not prosecuting would be in breach of international law.

The duty to prosecute varies according to the category of international crime and remains contentious with respect to certain international crimes. Due to space constraints, we will only touch upon this debate superficially. The common view to which we adhere is that there is a duty to prosecute only when stipulated by treaty law. ${ }^{28}$ In Uganda, the accusations specifically concern war crimes committed in non-international armed conflicts and crimes against humanity. With reference to war crimes committed in non-international armed conflicts, the duty to prosecute is not solidly established in treaty law..$^{29}$ As for crimes against humanity, no specialized treaty codifies their applicable rules, including the prosecution of such crimes. $^{30}$

In sum, the boundaries set by general international law do not clearly outlaw the practice of not prosecuting the alleged gross violations of international law committed by LRA members in Uganda. The ICC could thus, in principle, recognize the legal framework of alternative justice mechanisms - the amnesties - for crimes committed in Uganda. Another fundamental question is whether these plans would be acceptable under the statutory basis for the ICC to stop the proceedings it has undertaken. Indeed, because these proceedings have passed the state of the investigation and charges have been issued,

\section{"The choice of alternative mechanisms of justice is made within the realm of State sovereignty, unbound by a clear duty to prosecute in Uganda."}

their replacement involves withdrawing the case from the Court. It will thus be necessary to evaluate whether the Rome Statute allows for the substitution with non-prosecutorial methods of justice. 
Legal Basis in ICC Statutory Law ${ }^{31}$

Deferral by the Security Council

Three provisions of the Rome Statute have been identified as entry points to withdraw ICC prosecutions, which, once halted, would be replaced, by TRCs or traditional means of justice. A first mechanism provided for in the Rome Statute for a case to be withdrawn from the jurisdiction of the ICC is for the Security Council to defer it. This competence is regulated by article 16 of the Rome Statute. According to this provision, the Security Council can adopt a resolution under Chapter VII of the UN Charter requesting the abrogation of investigations or prosecutions for a period of twelve months. The request may be renewed under the same conditions. ${ }^{32}$ Morten Bergsmo and Jelena Pejic argue that when negotiating article 16 , the drafters were mindful of political stalemates exemplified in situations such as Uganda's, where peace and justice seem to be in conflict..$^{33}$ In this case, for Vera Gowlland-Debbas, international law prescribes that the objective of maintaining or securing peace prevails as chapter VII resolutions overcome, by law, other obligations. ${ }^{34}$ In that spirit, the provision has been described by Gowlland-Debbas as, "... the vehicle for resolving conflicts between the requirements of peace and justice where the Council assesses that the peace efforts need to be given priority over international criminal justice." ${ }^{\prime 35}$ If this is true, then the deferral is a viable means to allow for some amnesties. ${ }^{36}$

Article 16 of the Rome Statute is ambiguous regarding its role in shaping proceedings substituting ICC prosecutions when deferring a case. Indeed, the Rome Statute does not stipulate that a Security Council deferral be accompanied by effective action by that body to maintain or restore international peace and security, e.g. a program of accountability for perpetrators of international crimes, as previous drafts of article 16 have mandated. ${ }^{37}$ However, the final version of the article, as adopted, favored giving the Security Council a wide margin of discretion. Accordingly, the Security Council can consider that the deferral per se constitutes a sufficient action; it could also alternatively take a step further and decide upon the adoption of further measures to this end. In the absence of a clear relationship between a Security Council deferral and the nature of substitute methods of accountability prosecutorial or not - the national system of a State is temporarily relieved of its obligations to the ICC.

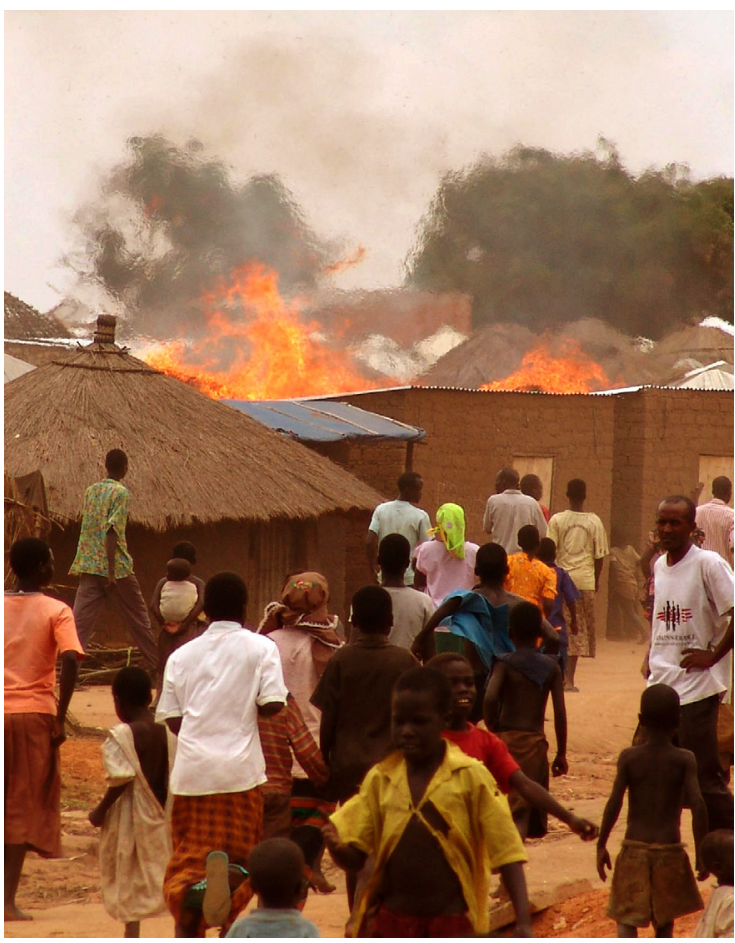

A fire sweeps through a refugee camp for those displaced by the conflict between the Lord's Resistance Army and the Ugandan Government

Thus, if the Security Council deferred the case of Uganda, the substitute mechanisms of accountability put in place by Uganda could take many forms, as long as they are in line with the Council's duty to preserve peace and security. ${ }^{38}$ In the eyes of the international community, the choice of alternative mechanisms of justice is made within the realm of state sovereignty, unbound by a clear duty to prosecute in Uganda. In short, when a case is deferred at the Security Council, one should be "...acutely 
conscious that [the] indiscriminate exercise of this power in purported pursuit of peace will emasculate the ICC, and undermine efforts to strengthen deterrence and institutionalize human rights norms." ${ }^{\prime \prime 9}$ On the other hand, the deferral could allow for valuable nonprosecutorial mechanisms to be employed in order to administer justice.

\section{Withdrawal through Complementarity}

Complementarity is another way by which an ICC case can be withdrawn. Complementarity signifies that the ICC recognizes the primacy of national jurisdictions, to which it is complementary, over its own. Thus, the Court cannot take a case when a state exercises its jurisdiction over the crimes set out in the Rome Statute in circumstances defined in article 17, namely genuine ability and willingness of domestic judicial proceedings..$^{40}$ The ICC should however assume jurisdiction in certain circumstances, even where national investigations or prosecutions have occurred, but lacked 'genuineness'. What is more relevant to the case of Uganda is that when considered a contrario, the wording of the article 17 provides that the ICC may stop an investigation or prosecution on the basis that it is inadmissible, even when proceedings are already underway at the ICC. This is made clearer under paragraph 2 of article 19, which allows the states ordinarily having jurisdiction over a case and persons accused or summoned by the Court to challenge the admissibility of the case at the ICC. This practice is called a 'challenge.' To be successful, the challenger will however need to prove that the proceedings substituting those of the ICC are genuine, that is, that they are a product of the state's willingness and ability, i.e. that substitute proceedings meet international legal standards. ${ }^{41}$

To this day, the ICC has developed no substantive case law on the admissibility of cases. ${ }^{42}$ It can however be speculated that if one follows a strict interpretation, article 17 does not warrant the admissibility of certain amnesties if they are supplemented by investigations. Yet, on the contrary, it can be argued that article 17 leaves room for the inadmissibility of these amnesties when the article is interpreted widely. ${ }^{43}$ To discuss this, we look at articles 17(1) and 17(2). Both provisions rule when a case is inadmissible.

First, under article 17(1)(a), a case is inadmissible where, "... it is being investigated or prosecuted by a state which has jurisdiction over it..."44 For some commentators, the use of the word 'or' can suggest that all that is required to preserve the primacy of a national process is that one or the other proceedings be in progress. Thus, if a case is investigated but not prosecuted, the ICC cannot assume jurisdiction. Additionally, since the Statute does not specifically require that an investigation be criminal or police-related, it would seem a quasi-judicial investigation is sufficient so long as its goals meet the standards expected of a criminal investigation: i.e. it establishes the facts and the responsibility of a crime through a systematic inquiry. ${ }^{45}$

The context of the article, however, suggests that certain conditions limit investigations that could be acceptable under article 17. First, article 17(1)(b) seems to contain such a condition. The article's subparagraph addresses a similar situation as paragraph (a), yet differs in that it does not apply to cases currently being investigated, but rather, to cases investigated in the past. Paragraph (b) however specifies further that when limiting itself to an investigation, the state must have made the "decision" not to prosecute. ${ }^{46}$ This condition appears to imply that prosecution must at least be an option for an investigation to meet the inadmissibility test of article $17 .{ }^{47}$

Further, articles 17(1)(a) and (b) both require the Court to determine whether the decision not to prosecute resulted from the genuine unwillingness or inability of the state. This again constrains the investigative alternative justice mechanisms that could withstand scrutiny by the Court. First, a relevant provision is 17(2), which details what is meant by 'unwillingness.' ${ }^{8}$ The chapeau 
of the article clarifies that the criterion of unwillingness shall be assessed with "... regard to the principles of due process recognized by international law..." ${ }^{49}$ This reference suggests that investigations, even if they are quasijudicial, must guarantee basic fair trial rights to the accused in the procedure. ${ }^{50}$ Similarly, paragraph (c) indicates that, to withstand scrutiny by the Court, an investigation should be conducted independently and impartially. ${ }^{51}$

Another relevant provision essential in evaluating the conformity of alternative justice mechanisms is article $17(2)(a)$. The article sets an additional constraint on investigations in that a case should not have been addressed by an investigation made "... for the purpose of shielding the person from criminal responsibility..." to be inadmissible to the Court. ${ }^{52}$ The prime concern of this provision was to preclude proceedings that deviate from awarding criminal responsibility, i.e. sham proceedings. ${ }^{53}$ As a result, as notes Carsten Stahn, where the prosecutor cannot prove that the intent of a proceeding is devious, or contrary to the apparent actions, alternative justice mechanisms may be validated as genuine proceedings. ${ }^{54}$ Thus, to fall below the threshold of this article and meet the Court's test of inadmissibility, alternative justice mechanisms should be “...guided by the (objective) aim to promote reconciliation, rather than by the (subjective) intent to twist and bend the rules of criminal trials for the purpose of impunity." 55

Finally, article $17(2)(c)$ constrains investigations that could withhold scrutiny. The article states that the proceedings must be conducted "...in a manner which [...] is consistent with an intent to bring the person concerned to justice." ${ }^{56}$ Interpreting this article depends on what is understood by the notion of 'justice'. If the notion is narrowly associated with criminal justice, there is little room for alternative justice mechanisms that do not retain the possibility of criminal prosecution. However, if the notion of restorative justice can be reconciled with more common conceptions of justice, then the granting of an amnesty is a possible outcome. In that case, the level of deference that the ICC will reward to alternative justice mechanisms may depend on whether their outcome implies a mandatory sanction. ${ }^{57}$ For example, the East Timorese TRC made the granting of impunity dependent on the performance of a visible'act of reconciliation', such as community service, reparation, a public apology and other acts of contrition. ${ }^{58}$

Another factor that can make a case inadmissible before the ICC is the inability criterion. However, as this criterion is exclusively linked to the issue of prosecutions carried out by the judicial system, as laid out by a provision in the Rome Statute, it is unnecessary for the Court to evaluate the conformity of quasi-judicial investigations to this criterion in order to assess their validity. Indeed, the only circumstances provided for in article $17(3)$ to identify the inability to undertake proceedings are the collapse or unavailability of a national judicial system. ${ }^{59}$ Since the alternative justice mechanisms contemplated are extra-judicial, there is no need to evaluate the ability of Uganda's judicial system. ${ }^{60}$

Recent TRCs have been construed, both procedurally and substantially, following those boundaries by which alternative justice mechanisms could be interpreted as prosecutions and could allow for a case to be withdrawn from the ICC. The TRC of South Africa and East Timor are good examples. Building on these experiences, this is a framework to which an eventual Ugandan TRC could conform in order to successfully challenge the ICC's complementary jurisdiction. Would Ugandan traditional justice mechanisms likewise meet the minimal requirements set for investigations by article 17 ?

In their present form, it is unlikely that traditional justice mechanisms would satisfy the test of article 17, as they would clash with some of the conditions discussed above. First, Ugandan traditional processes do not perform 
the function of an investigation. For instance, Mato Oput requires the establishment of facts, and the process is not final until the perpetrator has admitted his motivations for the crime, expressed remorse, and established the circumstances of the crime. ${ }^{61}$ Yet, critics have remarked that the investigation would exclude women, who only play a marginal role in the establishment of truth in Mato Oput. ${ }^{62}$ Further, Mato Oput clashes with article 17(1)(b) because it does not retain the option to prosecute as an outcome of the investigation should the accused for instance fail to cooperate with the investigative organ. Also, given the apparent lack of legitimacy of traditional justice ceremonies within the population, as previously discussed, one may question whether Mato Oput represents a genuine intent to bring perpetrators to justice as required by article $17(2)(\mathrm{c})$. Related to this, the sanctions provided by Mato Oput may be indicative of an intent to bring an individual to justice. In that regard, traditional ceremonies do require the public acknowledgement of wrongs, but only if this is done willingly. ${ }^{63}$ However, LRA leaders have repeatedly denied their crimes, and it is unlikely they will admit to them willingly. ${ }^{64}$ Illustrative of this is a conversation Professor Tim Allen reports he had with LRA brigadier Sam Kolo just before the latter was going through the healing rite. Allen reports that the ex-LRA member had signified to him the ceremony did not really mean anything to him. Further, while Mato Oput also provides for sanctions in the form of compensations, Kolo had also made clear to Professor Allen that he would not pay compensations to his victims. ${ }^{65}$

\section{Withdrawal through the 'Interests of Justice' Provision}

Article 53(2) of the Rome Statute appears to bestow the prosecutor with the necessary discretion to conclude that, when not in the 'interests of justice', there is not a sufficient basis for prosecution. ${ }^{66}$ Paragraph (c) further specifies that the prosecutor shall guide his decision by taking into account "all... circumstances", detailed in the remainder of the provision. ${ }^{67}$ The first question to address is whether it is indeed possible to drop a case on the basis of this provision. The standard test for interpreting treaty rules as laid down in article 31 of the Vienna Convention on the Law of Treaties (VCLT) forms the basis of interpretation of any provision found within a treaty. Article 31 calls for the interpretation of a treaty "... in good faith in accordance with the ordinary meaning to be given to the terms of the treaty in their context and in the light of its object and purpose." 68

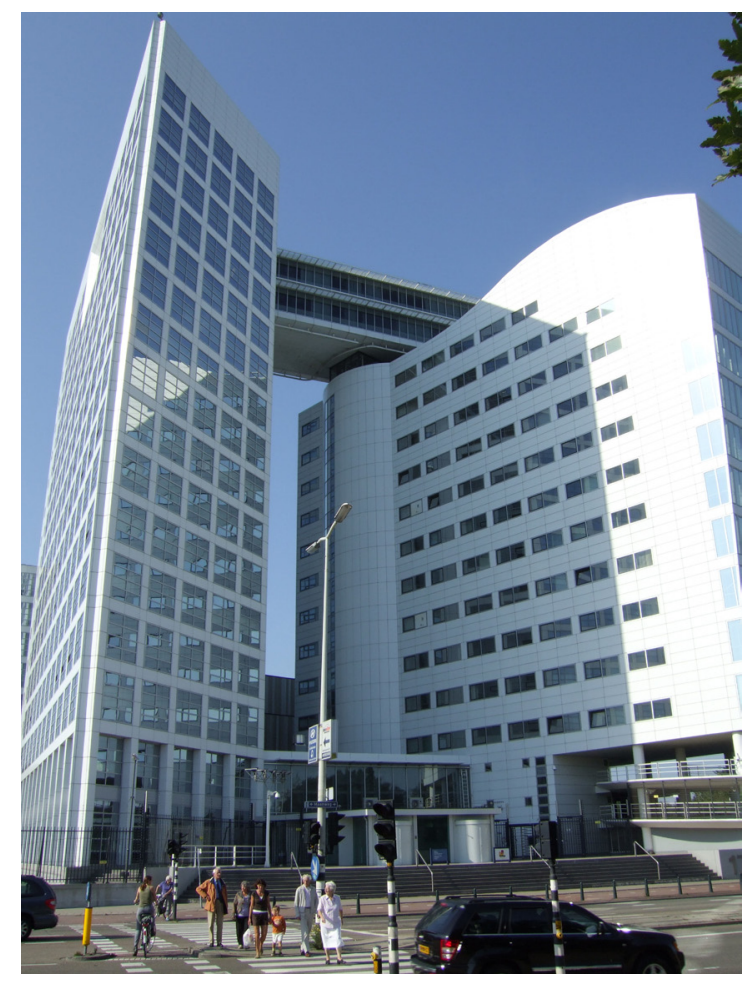

The International Criminal Court, located in The Hague, the Netherlands, prosecutes individuals accused of war crimes and crimes against humanity

Following this set of interpretative guidelines, an argument can be made to the effect that a non-prosecutorial program could be accommodated under this article 53. Indeed, the VCLT holds that, "[r]ecourse may be had to supplementary means of interpretation [...] to determine the meaning when the interpretation according to article 31: (a) leaves the meaning ambiguous or obscure." ${ }^{69}$ Commentators who have taken the 
position that the dropping of prosecutions is not permitted on the basis of the interests of justice predicate their argument on the object and purpose of the Rome Statute, which focuses on ending impunity for international crimes, and the punishment of these crimes. ${ }^{70}$ However, in the absence of ICC case law on this article to guide one's interpretation of the ordinary meaning of its terms - in particular the terms 'interests' and 'justice' the consideration of supplementary means of interpretation, such as the circumstances of a treaty's conclusion and its preparatory work, appears justified. ${ }^{71}$

Looking into the debate surrounding the adoption of article 53 affirms that alternative justice mechanisms could count as valid substitute mechanisms to prosecution at the ICC under this article. Indeed, the drafters did not define the exact content of 'interests of justice'. Rather, they left ambiguous their views on the issue of whether or not amnesties and TRCs would be invalidated by the Rome Statute. $^{72}$ As noted by Manjsuli Ssenyonjo, drafters would have addressed single amnesty or truth and reconciliation commission policies directly in the ICC Statute had they agreed on this in Preparatory Commission meetings preceding the Conference. For instance, drafters could have added a provision on the withdrawal of referrals. ${ }^{73}$ Rather, they left the authority to the ICC to develop jurisprudence on the matter - intentionally according to a number of individuals. ${ }^{74}$ Thus, in the light of its specific mandate, it is clear that the ICC must be committed to ending impunity through prosecution of the LRA leaders. However, the 'creative ambiguity' of article 53 does not appear to clearly preclude the prosecutor's use of the notion of interests of justice to drop prosecutions in favor of non-prosecutorial programs in exceptional cases. ${ }^{75}$

Returning to the case of Uganda, is it possible to drop the indictments in the 'interests of justice'? ? ${ }^{76}$ Many commentators are of the opinion that prosecutorial discretion is the most plausible avenue to accommodate alternative justice mechanisms, such as amnesty and TRCs. ${ }^{77}$ It is unclear, however, what level of deference the prosecutor will view as being appropriate when confronted with the decision as to whether to shelve indictments in the 'interests of justice.' Certainly, the prosecutor would base his position on general considerations of international law such as the duty to prosecute, as we have already done. Beyond that, the Rome Statute provides little guidance as to what 'interests of justice' could make a case inadmissible. As was seen in the previous discussion, article 53 nevertheless identifies circumstances that can be useful in offering guidance.

First, in reviewing whether respecting an amnesty and not prosecuting would better serve the 'interests of justice', the prosecutor would look at the circumstances to which the article obliges him to take into account. The 'interests of victims' appears to be the main parameter related to the notion of the 'interests of justice' that could argue in favor of dropping ICC prosecutions in the case of Uganda. However, this criterion lacks a clear definition. As was noted above, the provision seems to imply that certain factors can, at times, outweigh the paramount interest in having the accused criminally investigated and prosecuted. As Professor Allen suggests, taking into account the interests of the victims could imply that, "[a]t the very least, the victims can affect what it is appropriate for the Court

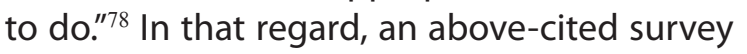
conducted with Northern Ugandans reveals that respondents seek both peace and justice, and that they are willing to have perpetrators granted amnesty, but not unaccountability. Looking at the details, 76 percent of the respondents want the perpetrators to be held accountable, with a preference for punishment (66 percent). In parallel however, 56 percent would favor the granting of amnesties, paired with measures such as an apology, and confession. ${ }^{79}$

In sum, the survey's results suggest that for victims, alternative justice mechanisms 
constitute an alternative avenue, but not necessarily to the exclusion of prosecution. As was discussed above, this is not a condition traditional Ugandan justice mechanism clearly meets, as Mato Oput for instance does not give the option of prosecuting. It is likely, however, that a TRC with a proper mandate, including an option to sanction, could meet the victims' expectations as suggested above. Furthermore, a majority of the survey's respondents wanted the opportunity to speak publicly about the abuses they had suffered, a goal that can also be fulfilled by a TRC. ${ }^{80}$

Commentators have also attempted to find additional guidelines that could likely guide the prosecutor. These guidelines are, however, tentative, lacking a clear judicial basis. Two broad criteria can be distinguished. First, the prosecutor should look at the validity of the substitute justice program the state will employ, evaluating for instance their democratic basis, the effectiveness of the investigation of the facts, and the existence of some type of sanctioning mechanism. ${ }^{81}$ Second, consideration should be given to the 'necessity' to depart from the standard criminal prosecutions. ${ }^{82}$

\section{"A majority of the survey's respondents wanted the opportunity to speak publicly about the abuses they had suffered, a goal that can also be fulfilled by a TRC."}

These standards also point to the likelihood that the prosecutor would not withdraw a case on the basis of the 'interests of justice', if substituted with traditional justice mechanisms. This can be perceived when evaluating the validity of the substitute justice program. As noted by Darryl Robinson, the required substitute justice mechanisms are not dissimilar from those relevant to a withdrawal based on complementarity discussed above, although not as clearly guided by legal criteria. ${ }^{83}$ In that context, the point was made that traditional justice mechanisms in Uganda are not adequate justice programs, a conclusion that is maintained even in the context of article 53.

'Necessity' to depart from the standard criminal prosecutions as outlined above concedes that prosecution that could further engender conflict is sufficient enough reason to decide not to prosecute international crimes. ${ }^{84}$ In that sense, the case has already been made that withdrawing prosecutions in Uganda is overwhelmingly perceived as necessary to ending the conflict and attaining peace. However narrowly should the necessity condition be interpreted, one can hardly envision a scenario more indicative of necessity than one where there is a clear tradeoff with peace. This criteria does not only flow from legal principles, but also from a political evaluation that the prosecutor is compelled to make. ${ }^{85}$

The bottom line is that prosecutorial discretion in all jurisdictions is a prerogative that vests the prosecutor with a strong liberty of action. In common law systems, the prosecutor typically enjoys the authority to select and pursue criminal cases. ${ }^{86}$ Normally, however, guidelines are promulgated to guide prosecutorial decision-making. At the ICC, such regulations are being drafted. Incidentally, they lean towards including consideration of circumstances in which an investigation or prosecution might "exacerbate or otherwise destabilize a conflict situation" or "seriously endanger the successful completion of a reconciliation or peace process." ${ }^{177}$ In spite of this, until they are applicable, the prosecutor's discretion remains, in principle, nearly unlimited. Certainly, the Pre-Trial Chamber may conduct a review of the prosecutor's discretionary decisions, ${ }^{88}$ but nothing indicates that the Pre-Trial Chamber will oppose the merits of dropping prosecutions if they are rigorously based on realistic political considerations.

Which Withdrawl Mechanism is Preferable? 
In retrospect, abandoning a case on the basis of complementarity or on the basis of the 'interests of justice' offer more positive contributions to the achievement of justice as a result of the strings these notions attach to the substitute procedure. As it is, article 16 provides that a case may be abandoned in isolation to the general framework of justice developed in the Rome Statute. In contrast, abandoning a case on the basis of the 'interests of justice' or on the principle of complementarity, requires the fulfillment of certain criteria with regard to the administration of justice. Thus, although the means of accountability put in place in Uganda are essentially a question of domestic standing, their choice is also closely linked to the legal regime put in place by the Rome Statute.

Indeed, initiating prosecutions at the ICC prompts the state to reinforce its domestic judicial system. Complementarity is a mechanism that encourages states to respect their obligation to investigate and prosecute major international crimes by acting as a catalyst for their compliance. ${ }^{89}$ According to the drafters of the Rome Statute, complementarity should have stimulated judicial activities as a consequence of the reluctance of States to surrender their national criminal jurisdiction to the ICC, i.e. before the Court would exercise its jurisdiction over it. The relationship between the concurrent jurisdictions would thus have been antagonistic. The practice of self-referrals has however, modified this calculation. Rather, the development of constructive tensions between the ICC and domestic jurisdictions has become a common function of complementarity when a State reclaims its criminal jurisdiction after having voluntarily dispensed with it, i.e. after the Court exercises its jurisdiction over it..$^{90}$ Thus, by taking decisions that involve constructing norms for what domestic criminal justice should look like for adjudicating international crimes, the Court has embarked on the course of setting minimum requirements for national standards of criminal justice systems throughout the world. ${ }^{91}$

Hence, when the Court exercises or threatens to exercise its jurisdiction on judicial proceedings, it pressures the state to raise its judicial standards. For example, the complementarity principle has prompted Uganda to raise the standards of its judicial system..$^{92}$ If it wishes to replace ICC prosecutions by its own, Uganda will likely need to prove its genuine willingness and ability to investigate or prosecute LRA leaders. In effect, the ICC's principle of complementarity has influenced Uganda into enhancing its prosecutorial capacity. This catalytic influence can be perceived from diverse direct indicators. For instance, Uganda has made efforts to adjust its judicial system to prosecute international crimes through the implementation of the Rome Statute, even though this is not an obligation in and of itself under the Statute. ${ }^{93}$ Furthermore, it has sought to introduce amendments to exclude the leadership of the LRA from receiving amnesties shielding them from criminal responsibility. ${ }^{94}$ All of these measures are aimed at facilitating a prosecution.

In the same way, the Court can decide to resist dropping prosecutions of LRA leaders until the alternative quasi-judicial mechanisms are sufficient in meeting the ICC's standards of adequacy. In other words, the ICC can pressure states to raise the standards of their alternative justice mechanisms. On this subject, the above discussion has revealed that the ICC would probably adopt a triple standard. If the case is deferred by the Security Council, the ICC would have little power to shape substitute justice mechanisms according to its own standards. With relation to the interests of justice clause, the scope of appreciation of the Court for non-penal proceedings would be broader than with relation to the complementarity notion. Indeed, the interests of justice clause does not force the ICC to inspect and approve the judicial system of a state as strictly as that of the complementarity clause. In contrast, under article 17, the scope of what substitute 
mechanism would be considered acceptable is much narrower as the complementarity regime sets a minimum requirement for a case to be dropped..$^{95}$

In sum, by adopting a broad approach to complementarity, the ICC has the opportunity to set minimum standards for nonprosecutorial alternative justice mechanisms. Ultimately, this is a chance to further both the general goals of international criminal justice, and those of the ICC to end impunity. This is not a negligible prospect; alternative justice mechanisms are bound to proliferate in correspondence with the multiplication of protracted internal conflicts. The adoption of such an approach would greatly enlarge the scope of accountability initiatives the Statute deals with. Indeed, as noted by Christopher K. Penny, "[c]ompared to amnesty and truth commissions, post-conflict criminal prosecutions is a relatively rare method of addressing atrocities." ${ }^{\prime \prime 6}$ Rather than declining the opportunity of measuring quasi-judicial mechanisms against its standards, the ICC should thus shape a policy of complementarity by which it engages with the common reality of quasi-judicial mechanisms.

\section{Conclusion}

This article has explored the role of the ICC in promoting impunity for violations of international criminal law in Uganda. As was discussed, the case of Uganda at the ICC exemplifies a perceived peace vs. justice dilemma that threatens to stall the debate on means to fight impunity in internal conflicts. Indeed, as negotiating peace to resolve protracted internal conflicts becomes more common and, in parallel, the ICC's complementary jurisdiction compels states parties to the Court to commit to prosecuting international criminals, these priorities often seem to clash.

However, this article has shown that it is possible to evade the tragic difficulties of choosing between peace and justice. Indeed, the appearance of exclusive options is arguably no more than the result of an ideological choice. While all societies distinguish between good and evil, addressing this through the lens of retribution is one option among others. Another option that we have defended is the restorative paradigm of justice which appears to be equally valuable, if not more so than retributive justice in cases such as that of Uganda. Indeed, recent history has demonstrated that transitional societies benefit more from restorative means of justice which appears more sustainable than retributive justice. Moreover, restorative justice mechanisms often allow reaching the necessary political compromise to settle a peace deal. Political actors engaged in solving the conflict in Uganda have raised this debate to advocate that traditional Ugandan justice mechanisms provide benefits retributive mechanisms do not offer.

Further, mindful of the peace vs. justice dilemma, we proposed to discuss whether these alternative mechanisms of justice - TRCs and traditional justice mechanisms - could lawfully replace the ICC's program of prosecution. To do so, it was necessary to explore the general international legal obligations regulating amnesties, since they provide a legal context to the alternative justice mechanisms discussed. After concluding that the general international legal rule does not clearly preclude amnesties, we looked at its statutory basis. We found that in the case of Uganda, the Rome Statute contains three mechanisms that could allow for the withdrawal of the case at the ICC: a Security Council deferral, a withdrawal on the basis of 'interests of justice', and a withdrawal following a challenge of admissibility on the basis of complementarity.

Forall threemechanisms, we found that the case can be made that prosecutions can be dropped and substituted by alternative justice mechanisms. The mechanisms, however, place different conditions on the substituting domestic jurisdiction. First, the Security Council deferral only minimally discriminates 

incentive for the domestic jurisdiction to raise its standards. Second, the 'interests of justice' clause compels the state employing alternative justice mechanisms to raise them to a certain standard, but only on the basis of unclear, and therefore weak, guidelines. Finally, the withdrawal of a case on the basis of a challenge of the Court's complementarity offers a more significant contribution to justice. This is because complementarity can act as a catalyst, pressuring states to raise the standards of substituting domestic procedures - even quasi-judicial ones - to meet the criteria set out in the Rome Statute.

$$
\text { As a result of this, when }
$$
Ugandan justice mechanisms do not meet the standards required to allow the Court to drop a case. Thus, under these scenarios, the case of Uganda would be maintained at the ICC. Alternatively however, a TRC could meet the necessary threshold to withstand scrutiny by the Court, and allow for the dropping of the case of Uganda. In this case, the Court would have much to gain. On the one hand, it can raise the global standard of justice for all cases where accountability is dealt with in non-prosecutorial ways. On the other hand, it furthers peace by bringing satisfaction to the victims, while holding their aggressors accountable.

complementarity is involved in conditioning the appropriateness of a withdrawal - based

\section{Endnotes}

1 Sebastien Malo holds a Masters of International Affairs from the Graduate Institute of International and Development Studies in Geneva. He worked from the Department of Foreign Affairs and International Trade of Canada in 2008-2009, and is currently the Middle East and North Africa Editor for The Daily Star, a newspaper in Beirut, Lebanon.

2 --, 'Ugandan peace deal in danger of collapse' The National (Abu Dhabi 17 August 2009) <http://www.thenational.ae/apps/pbcs.dll/ article?A ID=20090818/FOREIGN/708179920/1017/ART> accessed 6 September 2009; United Nations Department of Public Information, 'Senior UN official warns of deadly dangers facing southern Sudan' (11 September 2009) Press Release <http://www.un.org/apps/news/story. asp?NewsID=32029\&Cr=sudan\&Cr1=> accessed 11 September 2009.

3 Warrant of Arrest for Joseph Kony ICC-02/04-01/05-53 (8 July 2005, amended 27 September 2005); Warrant of Arrest for Okot Odhiambo ICC02/04-01/05-56 (8 July 2005); Warrant of Arrest for Dominic Ongwen, ICC-02/04-01/05-57 (8 July 2005). Since the warrants were issued, two of the individuals summoned by the court have been killed, leaving the court with three effective warrants of arrest. See--,'Uganda: LRA Rebel Chief kills his Deputy' The Monitor (Kampala 14 April 2008); Decision to Terminate the Proceedings against Raska Lukwiya ICC-02/04-01/05-248 (11 July 2007).

4 Chandra Lekha Sriram, Confronting Past Human Rights Violations: Justice vs. peace in times of transition (Frank Cass, London 2004$)$ 1-6.

5 Human Rights Watch, 'ICC Takes Decisive Step for Justice in Uganda' (14 October 2005) <http://hrw.org/english/docs/2005/10/14/uganda11880. htm > accessed 15 February 2008; Amnesty International, 'Government must back first ever arrest warrants by International Criminal Court' (Press Release) (14 October 2005) <http://web.amnesty.org/library/Index/ENGAFR590102005?open\&of=ENG-UGA> accessed 14 February 2008.

6 For instance, in early 2004, the head of the Uganda government's Amnesty Commission joined members of Parliament and religious leaders from Northern Uganda in opposing the ICC investigation. --, 'Kony: Amnesty, not Arrest' All Africa News (The East African) (27 January 2004) <http:// allafrica.com/stories/200402170874.html> accessed 15 January 2008.

7 LRA peace negotiating spokesman Ayo is quoted as saying: "If ICC drops the case, then we will sign the peace agreement and peace will return to northern Uganda." See, --, 'Ugandan rebels refuse to sign peace deal while facing arrest warrants' The Associated Press cited by International Herald Tribune (London 11 October 2006) <http://www.iht.com/articles/ap/2006/10/11/africa/AF_GEN_Uganda_Rebels.php> accessed 12 April 2008.

8 In a 2008 report, the Security Council suggested that the ICC drop the case against rebel leaders in Uganda, saying "[i]n the near future, the Council may [...] be confronted with a request by the Ugandan government for the Council to grant a year-long suspension of investigation and prosecution by the International Criminal Court (ICC) in northern Uganda." According to the report, Security Council members could vote, under the leadership of the United Kingdom, in favor of a one year deferral of the ICC prosecutions in the Uganda case. UNSC 'Uganda/LRA' (Update Report No 1) (11 April 2008).

9 UNSC Presidential Statement 48 (2008) UN Doc S/PRST/2008/48

10 See e.g. Mark Kelman, A Guide to Critical Legal Studies (Harvard University Press, Cambridge Mass. 1987).

11 Mark A. Drumbl, Atrocity, Punishment and International Law (CUP, Cambridge 2007) 182-85.

12 Drumbl 185.

13 Manisuli Ssenyonjo, 'The International Criminal Court and the Lord's Resistance Army Leaders: Prosecution or amnesty?' (2007) 7 Int'I Crim. L. R. 361, 371. (Ssenyonjo-a).

14 Tim Allen, Trial Justice: the International Criminal Court and the Lord's Resistance Army (African Arguments, Zed Books, London 2006) 133 (Allen-a).

15 --, 'Peace First, Justice Later' (2005) Refugee Law Project Kampala Working Paper No 17, 1, 24 <http://www.refugeelawproject.org/resources/ papers/workingpapers/RLP.WP17.pdf> accessed 12 April 2008.

16 --, Roco Wat I Acoli: Restoring Relationships in Acholi-land: Traditional Approaches to Justice and Reintegration (Liu Institute for Global Issues, UBC, Vancouver 2005) 74 <http://www.ligi.ubc.ca/sites/liu/files/Publications/IRP/15Sept2005_Roco_Wat_I_Acoli.pdf> accessed 12 April 2008.

17 Tim Allen, 'Ritual (Ab)use? Problems with Traditional Justice in Northern Uganda' in Nicholas Waddell \& Phil Clark (eds), Courting Conflict? Justice, Peace and the ICC in Africa (Royal African Society, London 2008) (Allen-b).

18 Phuong Pham et al., International Center for Transitional Justice and U.C. Berkeley's Human Rights Center, 'Forgotten Voices: a Population-Based Survey on Attitudes about Peace and Justice in Northern Uganda' (Report) (July 2005)

19 See generally the seminal work of Priscilla B. Hayner, Unspeakable Truths (Routledge, New York 2001).

20 Martha Minow, Between Vengeance and Forgiveness: Facing History after Genocide and Mass Violence (Beacon Press, Boston 1999 ) 88-9. 
21 Charles Villa-Vicencio, 'Why perpetrators should not always be prosecuted: Where the International Criminal Court and Truth Commissions meet' (2000) 49 Emory L.J. 205, 211-14.

22 Mark S. Umbreit, Betty Vos, Robert B. Coates \& Elizabeth Lightfoot, 'Restorative Justice: An empirically grounded movement facing many opportunities and pitfalls' (2007) 8 Cardoso J. Conflict Resol. 511, 515.

23 Umbreit, 515-16.

24 Kent Greenawalt, 'Amnesty's Justice' in Robert I. Rotberg \& Dennis Thompson (eds), Truth v. Justice: The morality of truth commissions (Princeton University Press, Princeton 2000) 194-98. (Greenawalt-a)

25 The grid of analysis of conflict resolution theory offers a fruitful point of entry into this debate. See e.g. David Lanz, 'The ICC's Intervention in Northern Uganda: Beyond the Simplicity of Peace vs. Justice' (2007) Institute for Human Security Working Paper Series 1, 17-20.

26 The term "domestic amnesty" refers to a national or municipal law which has the effect of discharging from criminal prosecutions. In that sense, the 2000 Amnesty Act declares an amnesty “...3. in respect of any Ugandan who has at any time since the 26th day of January, 1986 engaged in or is engaging in war or armed rebellion against the government of the Republic of Uganda by - 1. actual participation in combat; 2 . collaborating with the perpetrators of the war or armed rebellion; 3. committing any other crime in the furtherance of the war or armed rebellion; or 4. assisting or aiding the conduct or prosecution of the war or armed rebellion." Amnesty Act 2000 (Uganda).

27 Traditionally, the duty to prosecute is seen binding states only, thus binding Uganda, but not the ICC who is neither a party to the relevant treaties, nor necessarily a subject of customary international law in this regard. Under modern international however, it is generally accepted that international organizations and especially bodies concerned with ensuring and developing the rule of law internationally such as the ICC, should abide by the relevant rules of international law. See e.g. Henry Lovat, 'Delineating the Interests of Justice' (2007) 35 Denv. J. Int'I L. \& Pol'y 275, footnote 38; Naomi Roht-Arriaza, 'Amnesty and the ICC' in Dinah Shelton (ed), International Crimes, Peace, and Human Rights (Transnational Publishers, Ardsley NY 2000) 78.

28 See for e.g., Christopher C. Joyner, 'Redressing Impunity for Human Rights Violations' (1998) 26 Denv. J. Int'I L. \& Pol'y 591; Carla Edelenbos, 'Human Rights Violations: A duty to prosecute?' (1994) 7 Leiden J. Int'l L. 5; Naomi Roht-Arriaza, 'Non-treaty Sources of the Obligation to Prosecute?' in Naomi Roht-Arriaza (ed), Impunity and Human Rights in International Law and Practice (OUP, Oxford 1995); Diane Orentichler, 'Settling Accounts: The duty to prosecute human rights violations of a prior regime' (1991) 100 Yale L. J. 2537.

29 See e.g. Denise Plattner, 'The Penal Repression of Violations of International Humanitarian Law Applicable to Non-International Conflicts' (1990) 30 IRRC 414; Sonja Boelaert-Suominen, 'Grave Breaches, Universal Jurisdiction and Internal Armed Conflict: Is customary law moving towards a uniform enforcement mechanism for all armed conflicts?' (2000) 5 J. Conflict and Security L. 63. A competing view holds that, according to an emerging customary rule, certain crimes committed in non-international armed conflicts should be prosecuted on the basis of the same system of 'grave breaches' (codified in the Geneva Conventions and their Additional Protocol I) with which war crimes committed in international conflicts are prosecuted. See e.g. Antonio Cassese, International Criminal Law (OUP, Oxford 2008) 88.

30 Faustin Z. Ntoubandi, Amnesty for Crimes against Humanity under International Law (Martinus Nijhoff Publishers, Leiden 2007) 132. A minority of commentators argue that a custom to prosecute crimes against humanity has recently developed. See Bruno Simma \& Andreas L. Paulus, 'The Responsibility of Individuals for Human Rights Abuses in Internal Conflicts: A positive view' (1999) 93 Am. J. Int'I L. 302, 310; M.Cherif Bassiouni \& E.M. Wise, Aut Dedere Aut Judicare: The duty to extradite or prosecute in international law (Dordrecht, Boston and Martnus Nijhoff Publishers, Leiden 1995) 21.

31 This section builds on the work of Jessica Keller, who conducted a discussion similar to the one undertaken. Keller, however, comes to a different set of conclusions. See Jessica Keller, 'Achieving Peace with Justice: the International Criminal Court and Ugandan Alternative Justice Mechanisms' (2007) Thomas Jefferson School of Law Legal Studies Research Paper No. 1018539 1,39 <http://papers.ssrn.com/sol3/papers.cfm?abstract_ id=1018539> accessed 19 April 2008

32 Rome Statute of the International Criminal Court (adopted 17 July 1998, entered into force 1 July 2002) U.N. Doc. A/CONF.183/9, art 16. The source of the power of the Security Council to defer proceedings before the ICC stems from its responsibility to maintain international peace and security. Luigi Condorelli \& Santiago Villalpando, 'Referral and Deferral by the Security Council' in Antonio Cassese, Paula Gaeta \& John R.W.D. Jones (eds) The Rome Statute of the International Criminal Court: A commentary (OUP, Oxford 2003) 646. The responsibility to maintain international peace and security is enshrined in Article 24 of the UN Charter, which states: 'In order to ensure prompt and effective action by the United Nations, its Members confer on the Security Council primary responsibility for the maintenance of international peace and security, and agree that in carrying out its duties under this responsibility the Security Council acts on their behalf.'This is further complemented by actions the Council may take under Chapter VII of the Charter when having determined the existence of a threat to peace, breach of peace, or act of aggression. Article 39 of the UN Charter States: 'The Security Council shall determine the existence of any threat to the peace, breach of the peace, or act of aggression and shall make recommendations, or decide what measures shall be taken in accordance with Articles 41 and 42 , to maintain or restore international peace and security.' United Nations Charter (adopted 26 June 1945, entered into force 24 October 1945).

33 Morten Bergsmo \& Jelena Pejic, 'Article 16: Deferral of investigation or prosecution' in Otto Triffterer (ed), Commentary on the Rome Statute of the International Criminal Court (Kluwer Law International, The Hague 1999) 377.

34 United Nations Charter, art 103. Vera Gowlland-Debbas, 'The Role of the Security Council in the New International Criminal Court from a Systemic Perspective' in Laurence Boisson de Chazournes and Vera Gowlland-Debbas (eds), The International Legal System in Quest of Equity and Universality: Liber Americorum Georges Abi-Saab (Kluwer Law International, The Hague 2001), 629-50.

35 Bergsmo, 378.

36 This opinion is defended by e.g., Yasmin Naqvi, 'Amnesty for War Crimes: Defining the limits of international recognition' (2003) 85 IRRC 583, 592 Darryl Robinson, 'Serving the Interests of Justice: Amnesties, truth commissions and the International Criminal Court' (2003) 14 Eur. J. Int'I L. 482, 502-03 (Robinson-a). For contrary opinions, See Jennifer J. Llewellyn, who makes the remark that the Security Council deferral is only valid for one year, and as a result does not resolve the question of the validity of an amnesty. Jennifer Llewellyn, 'A Comment on the Complementarity Jurisdiction of the International Criminal Court' (2001) 24 Dalhousie L.J. 192.

37 Condorelli, 648.

38 The UN Charter also requires that actions should be consistent with the purposes and principles of the UN, including the promotion and respect of human rights. United Nations Charter, art 24(2). Thus if preexisting law required prosecution, it is not clear that the Security Council could override it through a deferring resolution. As this is not clearly the case with the crimes at hand, a Security Council deferral would probably not breach this provision.

39 Nick Grono, International Crisis Group, 'Negotiating Peace and Justice: Considering Accountability and Deterrence in Peace Processes' (Presentation at the International Conference on Building a Future on Peace and Justice in Nuremberg 2007) <http://www.crisisgroup.org/home/index. $\mathrm{cfm}$ ? id $=4922 \& \mathrm{l}=2>$ accessed 18 April 2008.

40 It is the Court that has the responsibility to determine the admissibility of a case. The chapeau of Article 17 States that "...the Court shall determine that a case is inadmissible." Rome Statute art 17.

41 Rome Statute, art 19.

42 See Decision on the admissibility of the case under article 19(1) of the Statute ICC-02/04-01/05-377 (10 March 2009) 11-12; 27.

43 See Llewellyn, 202-04; Carsten Stahn, 'Complementarity, Amnesties and Alternative Forms of Justice: Some interpretative guidelines for the 
International Criminal Court' 3 J. Intl' Crim. J. 695, 709-16; Claudia Cardenas Aravena, 'The Admissibility Test Before the International Criminal Court Under Special Consideration of Amnesties and Truth Commissions' in Jann K. Kleffner \& Gerben Kor (eds), Complementary Views on Complementarity (TMC Asser Press, The Hague 2006). For a contrary opinion, see John Dugard, 'Possible Conflicts of Jurisdiction with Truth Commissions' in Antonio Cassese, Paula Gaeta \& John R.W.D. Jones (eds), The Rome Statute of the International Criminal Court: A commentary (OUP, Oxford 2003) 501-03.

44 Rome Statute, art 17(1)(a).

45 Llewellyn, 203; Stahn, 710-11; Darryl Robinson, 'Comments on Chapter 4 of Claudia Cardenas Aravena' in Jann K. Kleffner \& Gerben Kor (eds), Complementary Views on Complementarity (TMC Asser Press, The Hague 2006) 144-45 (Robinson-b).

46 Rome Statute, art 17(1)(b).

47 Llewellyn, 203; Stahn, 712; Robinson-b, 144-45.

48 Stahn, 712.

49 Rome Statute, art 17(2).

50 Stahn, 712.

51 Rome Statute, art 17(2)(c). Stahn, 712.

52 Rome Statute, art 17(2)(a).

53 Sharon A. Williams, 'Article 17: Issues of Admissibility' in Otto Triffterer (ed), Commentary on the Rome Statute of the International Criminal Court (Kluwer Law International, The Hague 1999) 393.

54 Stahn, 714-15.

55 Stahn, 715.

56 Rome Statute, art 17(2)(c)

57 Stahn, 714-15.

58 UNTEAT Regulation No 2001/10, par. 27.7.

59 Rome Statute, art 17(3).

60 Cardenas Aravena, 135.

61 --, Roco Wat I Acoli, 55-6.

$62--$, Roco Wat I Acoli, 64; Peace Women, 'Perspectives and Experiences of Women in Northern Uganda in the ICC' (Press Release) (23 November 2004) $<$ http://www.peacewomen.org/resources/Uganda/WomenUgandaICC.html> accessed 20 March 2008.

63 Joanna R. Quinn, 'Beyond Truth Commissions: Indigenous Reconciliation in Uganda?' (2006) 4 The Review of Faith and International Affairs 31 , 36.

64 Joseph Kony appears to believe LRA atrocities were justified. He is reported to have stated: "If you picked up an arrow against us and we ended up cutting off the hand you used, who is to blame? You report us with your mouth, and we cut off your lips. Who is to blame? It is you!" Allen-a, 42.

65 Allen-a, 166

66 Rome Statute, art 53.

67 Article 53(2)(c) reads: "If, upon investigation, the Prosecutor concludes that there is not a sufficient basis for a prosecution because: ... (c) A prosecution is not in the interests of justice, taking into account all the circumstances, including the gravity of the crime, the interests of victims and the age or infirmity of the alleged perpetrator, and his or her role in the alleged crime; the Prosecutor shall inform the Pre-Trial Chamber and the State making a referral under article $14 \ldots$ of his or her conclusion and the reasons for the conclusion." Rome Statute, art 53(2)(c).

68 Vienna Convention on the Law of Treaties (adopted 23 May 1969, entered into force 27 January 1980) 1155_U.N.T.S. 331, 8 I.L.M. 679, art 31.

69 Vienna Convention, art 32

70 See e.g., Human Rights Watch, 'The Meaning of "the Interests of Justice" in Article 53 of the Rome Statute' (Policy Paper) (June 2005) 3-4 < www.hrw. org/campaigns/icc/docs/ij070505.pdf> accessed 14 February 2008.

71 Vienna Convention, art 32.

72 Bergsmo, 709.

73 Manisuli Ssenyonjo, 'Accountability of Non-State Actors in Uganda for War Crimes and Human Rights Violations: Between amnesty and the International Criminal Court' (2005) 10 J. Conflict \& Security L. 405, 425.

74 Gerhard Hafner et al., 'A Response to the American View as Presented by Ruth Wedgwood' (1999) 10 EJIL 108, 112. Darryl Robinson suggests on the basis of his presence at the negotiations that the lack of clear guidelines derived from the negotiation process is intentional. Robinson-a, 483. This hypothesis appears to be further confirmed by Philippe Kirsch, the Chairman of the Rome Diplomatic Conference. According to an interview with Mr. Kirsch, "... the provisions that were adopted reflect 'creative ambiguity' which could potentially allow for the prosecutor and judges of the International Criminal Court to interpret the Rome Statute as permitting recognition of an amnesty exception to the jurisdiction of the court." Michael P. Scharf, 'The International Criminal Court: Consensus and Debate on the International Adjudication of Genocide, Crimes Against Humanity, War Crimes, and Aggression' (1999) 32 Cornell Int'I L.J. 521-22.

75 See e.g. Robinson-a, 485-6.

76 Arguably, the prosecutor has already taken a position on the question. Indeed, under article 53(1)(c), the prosecutor must preclude proceedings as early as before the investigation if this is not in the interests of justice. Rome Statute art 53(1)(c). Considering this was not done before the investigation of the situation of Uganda was carried out, the prosecutor implicitly affirmed that proceeding was in the interests of justice. The prosecutor's analysis may however be re-opened at any time, under article 53(4), based on "...new facts or information." Rome Statute art 53(4) For Morten Bergsmo and Pieter Kruger, these new facts "... would have to be of such a nature as to create the possibility that they could eliminate the former shortfall in the information which led to the decision." Bergsmo, 714. Undoubtedly, in the event of an historical peace treaty in Uganda, the prosecutor could consider that a trade-off for amnesty qualifies in that regard.

77 See e.g. Dugard, 486

78 Allen-a, 129.ThisisalsoaviewtheICChasembracedindiscussingitspolicyorientation.TheICCpaperonpolicyissuespublishedinlate2003 indeednotes: "TheProsecutorwillencourageStates and civil society totake ownership of the Court...",and his office"...will take into consideration the need to respect the diversity oflegal systems, traditionsand cultures."ICC-OTP,'ICCPaperonSomePolicylssues Before theOffice of theProsecutor'(September 2003),2-5 <http://www.icc-cpi.int/library/organs/otp/030905_Policy_Paper.pdf> accessed 19 January 2008.

79 Pham.

80 Pham.

81 Thomas Hethe Clark, 'The Prosecutor of the International Criminal Court, Amnesties, and the "Interests of Justice": Striking a Delicate Balance' (2005) 4 Wash. U. Global Stud. L. Rev. 389, 408-09; Robinson-a, 497-98.

82 Robinson-a, 497.

83 Robinson-a, 500

84 Orentichler 2548; Juan E. Méndez, 'Accountability for Past Abuses' (1997) 19 Human Rights Quarterly 4.

85 See e.g. Alexander K.A. Greenawalt, 'Justice Without Politics? Prosecutorial Discretion and the International Criminal Court' (2007) 39 N. Y. U. J. Intl' L. 583. (Greenawalt-b)

86 Greenawalt-b 599-600

87 International Criminal Court, Draft Regulations of the Office of the Prosecutor (3 June 2003) 47 <http://www.icc-cpi.int/library/organs/otp/draft- 
regulations.pdf > accessed on 3 April 2008.

88 Rome Statute art 53(3)(b).

89 See Jann K. Kleffner,'Complementarity as a Catalyst for Compliance' in Jann K. Kleffner \& Gerben Kor (eds), Complementary Views on Complementarity (TMC Asser Press, The Hague 2006).

90 Kleffner 84-8.

91 Eric Blumenson, 'The Challenge of a Global Standard of Justice: Peace, Pluralism and Punishment at the International Criminal Court' (2006) 44 Colum. J. Transnat'I L. 801, 804-05.

92 This initially raised some questions as to how it would impact an eventual challenge to the case's admissibility under ICC jurisdiction. For many commentators the fact that the case of Uganda was not initially deemed admissible on the basis of Uganda's judicial system's unwillingness or inability, but rather because Uganda had willingly kept inactive and not initiated any proceedings, called for a different operationalization of complementarity. Indeed, when there is such a waiver of the state to exercise complementarity, it is unclear what consequences this should have on the state's efforts to reclaim its primary jurisdiction. For Mohamed M. El Zeidy, the state may outright not be allowed to request a withdrawal of the case on the basis of complementarity. Mohamed M. El Zeidy, 'The Ugandan Government Triggers the First Test of the Complementarity Principle' (2005) 5 Int'l. Crim. L.R. 83, 108-09. On the contrary, suggests Payam Akhavan, this could rather result in that there may be no requirement for the reclaiming state to establish its willingness or ability as a precondition for the exercise of jurisdiction since this was not a concern in the first place. Payam Akhavan, 'The Lord's Resistance Army Case: Uganda's Submission of the First State Referral to the International Criminal Court' 99 Am. J. Intl' L. 403,414 . If these interpretations are confirmed, the complementarity principle may well lose its capacity to act as a catalyst for compliance. It is however unlikely that the ICC, who is the prime judge of when it should initiate the exercise of its jurisdiction under article 13 of the Rome Statute, will adopt such a limiting interpretation. The notion that the ICC admits cases on the basis of "inaction" as a sufficient basis for admissibility is cautioned by an interpretation of Article 17 developed in an informal expert paper prepared for the Office of the Prosecutor in 2003, in which experts developed the condition. The experts purport to find a third contingency in the two contingencies specified in Article 17(1)(a): "...the most straightforward scenario is where no State has initiated any investigation (the inaction scenario). In such a scenario, none of the alternatives of arts. 17(1)(a)-(c) are satisfied and there is no impediment to admissibility. Thus there is no need to examine the factors of unwillingness or inability; the case is simply admissible under the clear terms of Article 17." ICC-OTP, 'Informal Expert Paper: The principle of complementarity in practice' (2003), paras 17-8 <http://www.icc-cpi.int/library/organs/otp/complementarity.pdf> accessed 19 January 2008.

93 Barney Afako, 'Country Study V: Uganda' in Max Du Plessis and Jolyon Ford (eds) Unable or Unwilling? Case Studies on Domestic Implementation of the ICC Statute in Selected African Countries (ISS Monograph Series, Institute for Security Studies, Pretoria 2008) 95.

94 Afako 96.

95 Robinson-a, 498-500.

96 Christopher K. Penny, 'Can Justice and Peace be Reconciled?'The Role of International Criminal Law' in Helene Dumont \& Anne-Marie Boisvert (eds), La voie vers la Cour Penale Internationale: Tous les chemins menent a Rome (Editions Themis, Montreal 2004) 151.

Photos Courtesy of:

"Fire in Parabongo IDP camp, Uganda." Wikimedia. 1 Nov 2009. http://commons.wikimedia.org/wiki/File:Fire_in_Parabongo_IDP_camp, Uganda.jpg

"Building of the International Criminal Court in The Hague." Wikimedia. 1 Nov 2009. http://commons.wikimedia.org/wiki/File:Building_of_the_ International_Criminal_Court_in_The_Hague.jpg 